\title{
STRATEGI PEMBELAJARAN ANAK USIA DINI
}

\author{
Oleh : Nurmadiah
}

\begin{abstract}
Abstrak
Pendidikan Anak Usia dini yang kemudian disingkat dengan PAUD merupakan salah satu lembaga pendidikan yang kini menjadi perhatian dikalangan dunia pendidikan. Sehingga sudah menjadi suatu kebutuhan bagi para pemerhati dan pengambil kebijakan pendidikan untuk memperhatikan dam memikirkan strategi apa yang terbaik untuk diterapkan dalam pelaksanaan pembelajaran di lembaga PAUD. PAUD adalah suatu upaya pembinaan yang ditujukan bagi anak sejak lahir sampai dengan anak usia enam tahun yang dilakukan melalui pemberian rangsangan pendidikan untuk membantu pertumbuhan dan perkembangan jasmani dan rohani agar anak memiliki kesiapan dalam memasuki pendidikan lebih lanjut. Strategi pembelajaran diartikan sebagai setiap kegiatan, baik prosedur, langkah, maupun metode dan teknik yang dipilih agar dapat memberikan kemudahan, fasilitas, dan bantuan lain kepada siswa dalam mencapai tujuan-tujuan instruksional. Dalam bahasa sederhana strategi pembelajaran adalah siasat membelajarkan siswa menuju tercapainya tujuan instruksional. Strategi adalah pola umum rentetan kegiatan yang harus dilakukan untuk mencapai tujuan tertentu. Adapun strategi pembelajaran pada anak usia dini selalu mengedepankan aspek-aspek aktivitas bermain, bernyanyi (bergembira), dan bekerja dalam arti berkegiatan. Bermain, bernyanyi dan berkegiatan merupakan tiga ciri PAUD. Pendidikan aspek apapun hendaknya dilungkupi dengan keaktifan bermain, bernyanyi, dan berkegiatan atau bekerja. Ketiga hal ini akan mengasah kecerdasan otak, kecerdasan emosi, dan keterampilan fisik yang dilakukan dengan ceria, bebas, dan tanpa beban. Dalam strategi pembelajaran memuat berbagai alternatif yang harus dipertimbangkan untuk dipilih dalam rangka perencanaan pengajaran. Untuk melaksanakan suatu strategi tertentu diperlukan seperangkat metode pengajaran. Suatu program pengajaran yang telah diselenggarakan oleh guru dalam setiap kali tatap muka, bisa dilakukan dengan berbagai metode. Keseluruhan
\end{abstract}




\section{2 \\ JURNAL AL-AFKAR \\ Vol. III, No. 1, April 2015}

metode itu termasuk media pendidikan yang digunakan untuk menggambarkan strategi pengajaran.

Kata Kunci: Strategi Pembelajaran dan PAUD

\section{A. Pendahuluan}

Pendidikan Anak Usia Dini yang kemudian disingkat dengan PAUD merupakan dasar bagi perkembangan sikap, pengetahuan, keterampilan, daya cipta, dan penyesuaiannya dengan lingkungan sosialnya. Oleh karena itu, perlu diusahakan agar pendidikan ini dapat dinikmati oleh segenap lapisan masyarakat. Hal ini perlu karena ada asumsi, sebaiknya anak-anak balita tinggal di rumah karena pendidikan dari ibunya merupakan pendidikan yang terbaik. Asumsi ini kurang tepat Pertama, ternyata kebanyakan ibu bekerja di luar rumah, sehingga anak tinggal bersama pembantu atau anggota keluarga yang lain, yang tidak tahu-menahu tentang pendidikan. Kedua, tidak semua ibu yang tinggal di rumah tahu cara mendidik. Biasanya, mereka membesarkan anak-anaknya berdasarkan apa yang diterima secara turun temurun, atau secara naluriah saja.

Berbicara masalah Pendidikan Anak Usia Dini, bukan merupakan hal yang baru. Hal ini dibuktikan oleh beberapa orang tokoh yang sejak lama telah membahas masalah PAUD, di antaranya:

Prof. Marjory Ebbeck (dalam Hibana) ${ }^{1}$, seorang pakar Anak Usia Dini dari Australia menyatakan bahwa pendidikan anak usia dini adalah pelayanan kepada anak mulai sejak lahir sampai umur delapan tahun.

1 Hibana S Rahman, Konsep Dasar Pendidikan Anak Usia Dini, (Yogyakara; PGTKI Press, 2005), hal. 3 
Nurmadiah

Soemiarti Patmonodewo ${ }^{2}$ dalam bukunya "Pendidikan Anak Prasekolah" memaparkan beberapa tokoh pendidikan anak usia dini di antaranya :

a. Jean Jacques Rousseau, menyarankan bahwa pendidikan anak usia dini hendaklah "kembali ke alam" (a return to nature) dan pendekatan yang digunakan bersifat alamiah yang dikenal dengan "naturalisme", dalam artian bahwa anak akan berkembang tanpa hambatan. Dengan pendidikan yang bersifat alamiah akan menghasilkan dan memacu berkembangnya kualitas semacam kebahagiaan, spontanitas, dan rasa ingin tahu.

b. Friederich Wilhelm Froebel, beliau dikenal karena menciptakan "Garden of children atau kindergarten" (taman kanak-kanak) pandangan Froebel terhadap pendidikan merupakan sarana untuk membantu perkembangan anak secara wajar. Ia menggunakan taman sebagai suatu simbol dari pendidikan anak. Dan pendidikan TK harus mengikuti sifat dari anak, bermain dipandang sebagai suatu metode dari pendidikan dan cara dari anak untuk meniru kehidupan orang dewasa dengan wajar. Dan kurikulum yang dirancang oleh Froebel meliputi pekerjaan, kegiatan seni dan keahlian dengan bermain lilin (clay), kayu dan kotak-kotak, juga dengan menggunting-gunting kertas, menganyam, melipat kertas serta menusuk-nusuk kertas. Adapun kegiatan lain menyanyi, bermain, berbahasa dan aritmatika.

2 Soemiarti Patmonodewo, Pendidikan Anak Prasekolah, (Jakarta; Rineka Cipta, 2003), hal. 3 
c. Maria Montessori, beliau adalah dokter dan antropolog wanita Itali yang pertama, Montessori memandang bahwa perkembangan anak usia dini merupakan suatu proses yang berkesinambungan. Dan Ia juga memahami bahwa pendidikan merupakan aktivitas diri, mengarah pada pembentukan disiplin pribadi, kemandirian dan pengarahan diri. Montessori menyebut sekolahnya dengan Casa Dei Bambini atau rumah anak. Adapun tujuan utama dari pendidikan ialah perkembangan secara individual yang menitik beratkan pada perkembangan fisik, sosial, emosional, dan ketrampilan intelektual yang meliputi: pengembangan konsentrasi, ketrampilan mengamati, kesadaran memahami tingkatan dan urutan, koordinasi, kesadaran dalam melakukan persepsi dan ketrampilan membaca dan menulis, terbiasa dengan halhal yang bersifat seni yang kreatif, memahami dunia alam lingkungan, memahami ilmu sosial, berpengalaman dengan ketrampilan yang bersifat teknik menyelesaikan masalah.

d. J.McVicker Hunt menyatakan bahwa dalam pendidikan prasekolah hendaklah sering melakukan program intervensi, sehingga dengan program ini akan dapat meningkatkan pengalaman anak, baik melalui pengamatan maupun percakapan.

Adapun tokoh-tokoh mutakhir dalam bidang PAUD di antaranya:

a. Constance Kamii, menurut Beliau pendidikan harus didasarkan pada tujuan jangka panjang suatu perkembangan dari seluruh kepribadian, khususnya 
ditekankan pada perkembangan intelektual dan moral. Dan bahwa konsep autonomy merupakan tujuan dari semua aspek bentuk pendidikan. Ia yakin bahwa anakanak sebaiknya mengetahui apakah pekerjaan yang dilakukan benar atau salah tanpa banyak bergantung kepada orang dewasa.

b. David Elkind, menurut Beliau bahwa anak-anak membutuhkan dukungan yang kuat untuk bermain dan berkegiatan yang dipilih sendiri dengan tujuan untuk dapat bertahan dalam stress yang ada sekarang dalam lingkungan anak. Dan Beliau percaya bahwa anak-anak tidak dapat dipersiapkan untuk menghadapi stress dengan mengalami lebih dahulu pada awal kehidupan mereka. Elkind mengingatkan akan bahaya terhadap pemaksaan anak-anak yang terlalu muda dengan tugas akademik yang belum waktunya.

c. Lilian Katz, menitikberatkan PAUD pada proses belajar mengajar. Dan tugas guru ialah memikirkan tentang dampak pendidikan terhadap pengalaman anak. Bagi Katz sekolah merupakan tempat pemerolehan pengetahuan, sikap, ketrampilan dan watak ${ }^{3}$.

Adapun di Indonesia, semenjak disahkannya Undang-undang Pendidikan Nasional No. 20 tahun 2003 yang di dalamnya menyinggung masalah PAUD, diikuti dengan pembentukan Direktorat PAUD, maka perkembangan PAUD terasa semakin mantap, kesadaran masyarakat juga semakin nyata. Hal ini ditunjukkan dengan maraknya pendidikan TK dimana-mana,

${ }^{3}$ Ibid, hal. 14 
sekaligus pendidikan guru TK dengan berbagai model. Tentu hal tersebut menjadi indikator positif bagi pengembangan kualitas PAUD. Adapun Undang-undang No. 20 tahun 2003, tentang SISDIKNAS pada bagian ke tujuh pasal 28 dijelaskan bahwa:

1. Pendidikan Usia Dini diselenggarakan sebelum jenjang pendidikan dasar.

2. Pendidikan Usia Dini dapat diselenggarakan melalui jalur pendidikan formal, nonformal, informal.

3. Pendidikan Usia Dini pada jalur formal berbentuk TK, Raudatul Athfal atau bentuk yang sederajat.

4. Pendidikan Usia Dini pada jalur nonformal berbentuk kelompok bermain (KB), Tempat Penitipan Anak (TPA), bentuk lain yang sederajat.

5. Pendidikan Usia Dini jalur pendidikan informal berbentuk pendidikan keluarga yang diselenggarakan oleh lingkungan. ${ }^{4}$

Menurut UU RI No. 21 Tahun 2003, tentang SISDIKNAS menyatakan bahwa PAUD ialah suatu upaya pembinaan yang ditujukan kepada anak sejak lahir sampai dengan usia enam tahun yang dilakukan melalui pemberian rangsangan pendidikan untuk membantu pertumbuhan dan perkembangan jasmani dan rohani agar anak memiliki kesiapan dalam memasuki pendidikan lebih lanjut.

Dalam PP RI No. 27 tahun 1990 tentang Pendidikan Prasekolah Bab I pasal 1 ayat 2 bahwa yang dimaksud dengan TK ialah salah satu bentuk Pendidikan Prasekolah yang menyediakan

\footnotetext{
4 Anwar Arifin. Memahami Paradigma Baru Pendidikan Nasional dalam UU SISDIKNAS, (Jakarta; Departemen Agama RI, 2003), hal. 46
} 
program pendidikan dini bagi anak usia empat tahun sampai memasuki pendidikan dasar. Dan berdasarkan keputusan Menteri Pendidikan dan Kebudayaan RI No. 0486/U/1992 Bab I pasal 2 ayat 1 bahwa TK merupakan wadah untuk membantu pertumbuhan dan perkembangan jasmani dan rohani anak didik sesuai dengan sifat-sifat alami anak. Selanjutnya yang dimaksud Anak Usia Dini menurut Biehler dan Snowman (1993), ialah mereka yang berumur 3-6 tahun ${ }^{5}$.

Berdasarkan beberapa pengertian di atas, dapat disimpulkan bahwa pengertian PAUD ialah upaya yang dilakukan oleh pendidikan secara terencana dan sistematis pada anak usia 0-8 tahun, dengan tujuan agar anak mampu mengembangkan potensi yang dimiliki secara optimal.

Secara umum tujuan program PAUD ialah memfasilitasi pertumbuhan dan perkembangan anak secara optimal dan menyeluruh sesuai dengan norma-norma dan nilai-nilai kehidupan yang dianut. Sehingga melalui program pendidikan yang dirancang dengan baik, anak akan mampu mengembangkan segenap potensi yang dimiliki dari aspek fisik, sosial, moral, emosi dan kepribadian ${ }^{6}$.

Adapun secara khusus tujuan dari PAUD ialah untuk :

a. Menyiapkan perkembangan kepribadian anak secara menyeluruh (memenuhi kebutuhan akan perkembangan intelektual dan kognitif, kebutuhan akan kegiatan yang kreatif dan kebutuhan untuk dapat berdiri sendiri)

b. Memenuhi kebutuhan emosi anak atau kebutuhan akan kasih sayang

6 Hibana S. Rahman, Op. Cit., hal. 6 


\section{8 \\ JURNAL AL-AFKAR \\ Vol. III, No. 1, April 2015}

c. Memenuhi kebutuhan akan hubungan sosial, pergaulan, kehidupan berkelompok dan bermasyarakat

d. Mengajarkan dasar-dasar pengetahuan atau mempersiapkan anak untuk masuk sekolah

e. Membantu perkembangan fisik dan otak anak

f. Memenuhi kebutuhan untuk berekspresi dengan bahasa.

g. Menanamkan ajaran-ajaran moral atau agama, kepahlawanan dan kewarganegaraan?.

PAUD merupakan salah satu bentuk penyelenggaraan pendidikan yang menitik beratkan pada peletakan dasar ke arah pertumbuhan dan perkembangan fisik (koordinasi motorik halus dan kasar), kecerdasan (daya pikir, daya cipta, kecerdasan emosi, kecerdasan spiritual), sosio emisonal (sikap dan perilaku serta agama) bahasa dan komunikasi, sesuai dengan keunikan dan tahap-tahap perkembangan yang dilalui oleh anak usia dini. Oleh karena itu, PAUD sedapat mungkin harus menjadi perhatian, baik menurut kebutuhan masyarakat luas, maupun menurut individu. Hal ini sejalan dengan pendapat yang dikemukakan oleh Dr. Nazali Shaleh Ahmad yang mengatakan bahwa :

Fase kanak-kanak merupakan salah satu fase kehidupan manusia yang cukup penting, artinya pada masa itu seorang anak sedang mengalami pertumbuhan fisik, kejiwaan maupun akal pikirannya yang mudah sekali menerima pengaruh dari berbagai faktor kehidupan di sekitarnya. ${ }^{8}$

Pendidikan seperti ini dimaksudkan untuk memberikan kesempatan kepada anak untuk belajar sedini mungkin, sehingga

\footnotetext{
7 Soedarjono, Pendidikan Prasekolah pada Beberapa Negara di Dunia, (Semarang; Mandira, 1988), hal. 52

8 Nazali Shaleh Ahmad, Pendidikan dan Masyarakat, (Yogyakarta; Bina Usaha, 1989), hal. 122
} 
tumbuh menjadi anak yang memiliki kelebihan ${ }^{9}$.

Selanjutnya PAUD merupakan awal bagi pertumbuhan dan perkembangan anak, karena hal itu akan membawa dampak bagi sepanjang kehidupan anak selanjutnya. Anak Usia Dini memiliki karakteristik yang khas baik secara fisik, psikis, sosial, moral, dan sebagainya. Masa kanak-kanak juga merupakan masa yang paling penting sepanjang usia hidupnya, oleh karena itu usia dini sering disebut dengan Golden Age (usia emas) yaitu usia yang sangat berharga dibandingkan dengan usia- usia selanjutnya. Karena pada anak usia dini merupakan individu yang sedang mengalami proses pertumbuhan dan perkembangan yang sangat pesat bahkan dikatakan sebagai lompatan perkembangan ${ }^{10}$.

Pengalaman yang dialami anak pada usia dini akan berpengaruh kuat terhadap kehidupan selanjutnya. Pengalaman tersebut akan bertahan lama bahkan tidak dapat terhapuskan kalaupun bisa hanya tertutupi. Bila suatu saat ada stimulasi yang memancing pengalaman hidup yang pernah dialami, maka efek tersebut akan muncul kembali walaupun dalam bentuk yang berbeda. Karena sedemikian pentingnya usia dini, maka perlulah kiranya bagi pendidik dan orangtua untuk memperhatikan perkembangan dan pendidikan yang akan dipersiapkan untuk anak usia dini, sehingga kita akan memiliki generasi yang mampu mengembangkan diri secara optimal.

PAUD juga memegang peranan yang sangat penting bagi sejarah perkembangan anak selanjutnya, anak yang mendapatkan pembinaan sejak dini akan dapat meningkatkan kesehatan dan kesejahteraan fisik dan mental, yang itu semua akan berdampak

\footnotetext{
9 Edy Gustian, Mempersiapkan Anak Masuk Sekolah, (Jakarta; Puspa Swara, 2001), hal. 36

${ }^{10}$ Hibana S. Rahman, Op. Cit., hal. 33
} 


\section{0 \\ JURNAL AL-AFKAR \\ Vol. III, No. 1, April 2015}

pada peningkatan prestasi belajar, etos kerja, dan produktivitas. Yang pada akhirnya anak akan lebih mampu untuk mandiri dan mengoptimalkan potensi yang dimiliki ${ }^{11}$

Program PAUD (0-8 tahun) memiliki beberapa bentuk organisasi. Tiap bentuk organisasi tersebut memiliki kekhasan masing-masing, secara rinci bentuk-bentuk program PAUD dapat diuraikan sebagai berikut:

\section{Pendidikan Keluarga (0-2 tahun)}

Pendidikan keluarga merupakan pendidikan pertama dan utama bagi anak, sebab pendidikan keluarga merupakan pondasi bagi anak untuk membangun struktur kepribadian selanjutnya.

\section{Taman-taman Pengasuhan Anak (TPA) (2-3tahun)}

TPA ialah lembaga kesejahteraan sosial yang memberikan pelayanan pengganti berupa asuhan, perawatan dan pendidikan bagi anak balita selama anak tersebut ditinggal bekerja oleh orangtuanya. TPA bertujuan membantu orangtua agar dapat bekerja dengan tenang sehingga tercapai prestasi kerja yang optimal. Selain itu juga menghindarkan anak dari kemungkinan terlantar pertumbuhan dan perkembangan jasmani dan rohani.

3. Kelompok Bermain (KB) atau play group (3-4 tahun)

KB merupakan tempat bermain dan belajar bagi anak sebelum memasuki Taman Kanak-kanak.

4. Taman Kanak-kanak (TK) (4-6 tahun)

TK merupakan jenjang pendidikan setelah $\mathrm{KB}$ sebelum anak masuk SD. Walaupun TK bukan jenjang pendidikan wajib 
diikuti, namun memberikan banyak manfaat bagi penyiapan anak untuk masuk SD.

\section{Sekolah Dasar (7-8 tahun)}

SD ialah jenjang pendidikan formal pertama setelah TK. Sehingga pada kelas tersebut idealnya pola pendidikan yang diterapkan tidak Jauh berbeda dengan pola pendidikan yang digunakan di TK.

Ki Hadjar Dewantara yang merupakan tokoh Pendidikan Taman Siswa, sangat menekankan bahwa untuk anak usia dini, kegiatan pembelajaran dan pendidikan itu hendaknya bersifat alamiah seperti bermain di "Taman". ${ }^{12}$

Untuk pendidikan di Taman Kanak-Kanak, Ki Hadjar menyebutkannya secara khusus dengan sebutan di Taman Indria ${ }^{13}$, pendidikan menuntun pertumbuhan dan perkembangan anak-anak sesuai dengan kodratnya sebagai anak, agar mereka memperoleh keselamatan dan kebahagiaan sebagai manusia merdeka. Ki Hadjar juga menganjurkan agar pada masa usia dini, anak jangan dicabut dari suasana keluarga dan dunia bermain mereka. Pembelajaran dan pelatihan kebiasaan semua di bungkus dalam permainan, suasana riang, oleh karena itu yang penting pada masa ini ialah pembiasaan dan pelatihan menggunakan indera serta persiapan untuk dapat membaca, menulis dan berhitung dengan latihan berbicara, menggambar, melukis, bernyanyi, menari, dan mengenal dunia lingkungan sempit mereka ${ }^{14}$.

\footnotetext{
${ }^{12}$ Theo Riyanto FIC, Martin Handoko FIC, Pendidikan pada Usia Dini, (Jakarta; Grasindo, 2004), hal. 9

${ }^{13}$ Karena alat-alat indera anak-anak mulai berfungsi dan perlu dilatihkan secara tepat pada masa ini.

${ }^{14}$ Theo Riyanto FIC, Martin Handoko FIC, Op. Cit., hal. 10
} 
Agar tidak terjadi kesalahan dalam PAUD, maka perlulah kiranya kita untuk memperhatikan masalah strategi pembelajaran pada Anak Usia Dini, dengan memperhatikan kekhasan dunia anak, karakteristik anak yang khas serta disesuaikan dengan ciriciri psikologi dan paedagogis serta tahap perkembangan moral mereka.

Strategi merupakan penggabungan berbagai macam tindakan untuk mencapai tujuan kegiatan. Pada TK kegiatan dapat dilakukan dalam bentuk bermain dan kegiatan yang lain. Dan strategi kegiatan lebih banyak menekankan pada aktivitas anak dari pada aktivitas guru ${ }^{15}$.

Di samping itu strategi pembelajaran Anak Usia Dini harus dilakukan dengan menarik, mensosial, penuh dengan permainan dan keceriaan serta tidak merampas dunia kanak-kanak mereka. Dan dalam strategi pembelajaran kita perlu mengembangkan dan memperhatikan pendekatan pembelajaran yang menjadikan mereka senang, asyik, kreatif dan aktif, sehingga lepas dari suasana tertekan, dan tidak terbebani. Adapun pendekatan-pendekatan itu ialah:

1. Active Learning (Belajar secara Aktif-Positif).

2. Attractive Learning (Belajar yang Mempesona dan Menarik Anak).

3. Joyful Learning (Belajar yang Mengasyikkan dan Menyenangkan).

4. Multiple Inteligence Approach (Pembelajaran yang Berdasarkan Konsep Kecerdasan yang Jamak $)^{16}$.

\footnotetext{
${ }^{15}$ Moeslichatoen R. M. Pd, Metode Pengajaran di TK, (Jakarta; Rineka Cipta, 2004), hal. 7

${ }^{16}$ Theo Riyanto FIC, Martin Handoko FIC, Op. Cit., hal. 4
} 
Dengan pendekatan-pendekatan pembelajaran diharapkan dapat dikembangkan aspek pengetahuan, perasaan, dan ketrampilan anak tanpa harus membebani mereka, kita juga berharap dapat melayani kebutuhan dan minat mereka, sehingga anak-anak beraktivitas tetap dalam keadaan ceria, asyik, gembira, sekaligus belajar bersosialisasi dengan teman mereka.

Disamping strategi pembelajaran Anak Usia Dini, perlu juga membangun suasana yang baik, sehingga para pendidik dapat bekerja dengan kasih sayang dalam suasana cinta kasih, pengertian, kerelaan dan kesabaran. Dalam proses pembelajaran yang demikian suasananya akan menghasilkan peserta didik yang patuh secara aktif dan dinamis. Anak tidak hanya menjadi objek pembelajaran tetapi lebih sebagai subjek pembelajaran. Pendidik lebih bersikap demokratis dan menempatkan dirinya sebagai fasilitator. Pendidik memberikan suasana pembelajaran yang "merdeka" sehingga hasil pendidikannya ialah siswa yang kreatif, mandiri, cerdas, taat pada hati nurani, bertanggung jawab dan tetap ceria ${ }^{17}$.

Namun pada kenyataannya banyak pihak yang berpandangan bahwa anak-anak itu bagaikan kertas putih, bersih. Orang dewasa bebas untuk menggambari, mewarnai, menulis, dan mencoreti, bahkan merobek atau meremas-remas kertas itu. Kegiatan orang dewasa tersebut sekarang ini terasa semakin menjadi-jadi, anakanak kecil harus melaksanakan banyak kegiatan. Mereka harus belajar di sekolah dengan banyak beban, karena harus menyerap banyak materi, mengerjakan sejumlah pekerjaan termasuk tugas dan pekerjaan rumah, sampai harus mengikuti kursus-kursus, melihat situasi semacam ini pastilah timbul pertanyaan dalam

\footnotetext{
${ }^{17} \mathrm{Ibid}$, hal. 6
} 
hati kita, apakah kegiatan-kegiatan sungguh sesuai dengan psikologi anak dan tahap perkembangannya?, apakah kegiatan dan tuntutan itu sungguh merupakan kebutuhan dan minat anak?, apakah kurikulum yang sarat materi dan membebani anak dengan pekerjaan ini sesuai dengan dunia anak yang masih membutuhkan suasana bermain, keceriaan, dan fantasi?

Inilah beberapa gejala-gejala yang terjadi di lapangan, bahwa tuntutan orangtua untuk menyelenggarakan berbagai macam aktivitas pembelajaran yang sebenarnya tidak tepat atau belum pada saatnya, oleh karena itu pihak pendidik selain memberikan pengertian tentang pembelajaran dan pendidikan yang tepat pada usia dini, juga hendaknya memahami suatu konsep tentang strategi pembelajaran yang tepat berdasarkan pada perkembangan psikologis, paedagogis dan dasar-dasar didaktik, serta mengacu pada kegiatan-kegiatan bermain, bernyanyi, bergerak (menari, dan berolah raga), singkatnya kegiatan pembelajaran dan pendidikan dalam suasana yang ceria, menyenangkan, menarik, dan mengasyikkan.

Budaya instan (mau serba cepat dan tanpa usaha) dan suasana kompetisi (persaingan), sudah sangat mempengaruhi cara berpikir dan perlakuan orang dewasa terhadap anak-anak kecil. Orangtua menginginkan anak-anaknya cepat menguasai sesuatu, dalam jumlah yang banyak dan lebih cepat dari pada anak-anak lainnya. Seolah-olah semakin cepat menguasai sesuatu, semakin banyak dan "hebat", semakin sehat dan baik bagi perkembangan kejiwaan anak. Padahal secara alamiah, kebutuhan, minat, dan kepekaan untuk mempelajari dan menguasai sesuatu membutuhkan proses, waktu, dan pelatihan yang sesuai dengan usianya, baik usia mental, fisik maupun usia kronologisnya. Orang dewasa 
tidak lagi memikirkan dan memperlakukan mereka sebagai orang dewasa mini. Kita bahkan menuntut mereka berpikir, merasakan, bersikap, melakukan sesuatu, berdaya tahan seperti orang dewasa.

Fenomena ini menunjukkan betapa beban belajar anak-anak kecil itu melampaui kemampuan mereka "overloaded", mereka kehilangan dunia kanak-kanak mereka yang penuh dengan suasana bermain, bernyanyi, menari, berfantasi (berkhayal), dan melakukan sesuatu tanpa beban. Mereka kehilangan kemerdekaannya sebagai anak kecil.

Oleh karena itu, sebagai pendidik perlulah kiranya mengembalikan praktek pendidikan dan pembelajaran pada usia dini. Kita kembalikan ruang kelas menjadi arena bermain, bernyanyi, bergerak bebas. Kita kembalikan ruang kelas sebagai ajang kreatif bagi anak dan menjadikan mereka secara psikologis nyaman. Kita bangun kembali suasana kelas yang penuh kekeluargaan, hangat, dan akrab, tidak lagi kita teruskan kelas menjadi ajang instruksi, indoktrinasi, dan pembebanan materi saja. Kembalikan kelas dalam suasana dimana setiap anak dihargai, diakui dan diberi kesempatan untuk berkembang. Dengan demikian mereka akan membangun rasa percaya diri dan nilainilai positifnya. Kita hilangkan sistem komando militer dengan menggunakan pendekatan asih.

\section{B. Pengertian Strategi Pembelajaran}

Istilah strategi pada mulanya digunakan dalam dunia kemiliteran. Strategi berasal dari bahasa Yunani strategos yang berarti jenderal atau panglima, sehingga strategi diartikan 
sebagai ilmu kejendralan atau ilmu kepanglimaan. ${ }^{18}$ Strategi dalam kamus bahasa Indonesia berarti siasat perang, ilmu siasat. Dalam pengertian merupakan rencana yang cermat mengenai kegiatan untuk mencapai sasaran yang khusus. Dalam ensiklopedia Indonesia ${ }^{19}$ disebutkan bahwa strategi ialah ilmu perang. Dimaksudkan manyusun dan mengatur perlengkapanperlengkapan pereang sedemikian rupa, sehingga kemenangan tercapai secepatnya. Pengertian strategi tersebut kemudian diterapkan dalam dunia pendidikan.Selanjutnya dalam Ensiklopedi pendidikan ${ }^{20}$ dijelaskan bahwa strategi adalah suatu seni, yaitu seni membawa pasukan kedalam medan tempur dalam posisi yang paling menguntungkan.

Perkembangan selanjutnya strategi tidak lagi hanya seni, tetapi sudah merupakan ilmu pengetahuan yang dipelajari. Dengan demikian istilah strategi yang diterapkan dalam dunia pendidikan, khususnya dalam kegiatan pembelajaran ialah suatu seni dan ilmu untuk membawakan pengajaran di kelas sedemikian rupa sehingga tujuan yang telah ditetapkan dapat tercapai secara efektif dan efisien.

Strategi pembelajaran selanjutnya dartikan sebagai kegiatan, baik prosedur, langkah, maupun metode dan teknik yang dipilih agar dapat memberikan kemudahan, fasilitas, dan bantuan lain kepada siswa dalam mencapai tujuan-tujuan instruksional. Dalam bahasa sederhana strategi pembelajaran ialah siasatmembelajarkan

${ }^{18}$ W. Gulo, Strategi Belajar Mengajar, ( Jakarta: Widiasarana Indonesia, 2002), h. 1

${ }^{19}$ Harsya, W. Bachtiar. Dkk, Ensiklopedi Indonesia jld 6, ( Jakarta: Ichtiar Baru Van Hoeve), h. 3308

${ }^{20}$ Soegarda Poerbakawatja. H. A.H. Harahap, Ensiklopedi Pendidikan, (Jakarta: Gunung Agung, 1981), h. 340 
Nurmadiah

siswa/i menuju tercapainya tujuan instruksional. ${ }^{21} \mathrm{Hal}$ serupa diungkapkan pula oleh Lalu Muhammad Azhar bahwa strategi pembelajaran merupakan sarana atau alat penggabungan berbagai macam tindakan untuk mencapai tujuan pembelajaran. Dengan demikian secara umum strategi pembelajaran lebih luas lingkupnya dibandingkan dengan prosedur dan metode. ${ }^{22}$

Selanjutnya menurut Prawirastrategi adalah cara mengerjakan sesuatu untuk mencapai tujuan tertentu, atau merupakan sebuah rencana permanen untuk sebuah kegiatan dimana didalamnya berisi formulasitujuan dan kumpulan rencana kegiatan. ${ }^{23}$ Menurut T. Raka Joni mengartikan strategi pembelajaran merupakan pola dann urutan umum perbuatan guru murid dalam mewujudkan kegiatan pembelajaran. Perbuatan atau kegiatan guru murid didalam proses pembelajaran itu terdiri atas bermacam-macam bentuk. Keseluruhan bentuk itulah yang dimaksud dengan pola atau urutan umum perbuatan guru murid. ${ }^{24}$ Menurut Djamarah bahwa strategi adalah suatu garis-garis besar haluan untuk mencapai tujuan yang telah ditentukan. Jika dihubungkan dengan pembalajran, strategi diartikan sebagai pola-pola umum kegiatan guru murid dalam mewujudkan kegiatan pembelajaran untuk mencapai tujuan yang telah digariskan. ${ }^{25}$

Strategi pembelajaran memuat berbagai alternatif yang harus dipertimbangkan untuk dipilih dalam rangka perencanaan

${ }^{21}$ Nana Sudjanam, Wari Suwariyah, Model-Model Mengajar CBSA, ( Bandung: Sinar Baru, 1991), h. 16

${ }^{22}$ Lalu Muhammad Azhar, Proses Belajar Mengajar Pola CBSA, (Surabaya: Usaha Nasional, 1999), h. 12

${ }^{23}$ Prawira Mangkut. Tb Syafri, manajemen Sumber Daya Manusia Strategik, (Jakarta: Ghalia Indonesia, 2003), h. 5

${ }^{24}$ T. Raka Joni, Strategi Belajar Mengajar, (Jakarta: P3G Depdikbud), h. 7

${ }^{25}$ Syaiful Bahri Djamarah, Aswan Zain, Strategi Belajar Mengajar, (Jakarta: Rineka Cipta, 2006), h. 5 


\section{8

pengajaran. Untuk melaksanakan suatu strategi tertentu diperlukan seperangkat metode pengajaran. Suatu program pengajaran yang diselenggarakan oleh guru dalam setiap kali tatap muka bisa dilakukan dengan berbagai metode. Keseluruhan metode itu termasuk media pendidikan yang digunakan untuk menggambarkan strategi pembelajaran. Menurut Syaiful Bahri Djamarah bahwa dalam strategi pembelajaran ada beberapa komponen yang selalu berkaitan di antaranya:

a. Mengindentifikasi serta menetapkan spesifikasi dan kualifikasi perubahan tingkah laku dan kepribadian.

b. Memilih sistem pendekatan pembelajaran berdasarkan aspirasi dan pandangan hidup masyarakat

c. Memilih dan menetapkan prosedur, metode, dan teknik yabg dianggap paling tepat

d. Menetapkan norma-norma atau batas minimal keberhasilan ata kriteria standar keberhasilan sehingga dapat dijadikan pedoman untuk melakukan evaluasi.

Dengan demikian dapat disimpulkan bahwa strategi adalah pola umum rentetan kegiatan yang harus dilakukan untuk mencapai tujuan tertentu. Dalam pelaksanaan strategi tersebut mengandung beberapa komponen yang saling terkait. Strategi pembelajaran ialah rencana dan cara-cara membawakan pengajaran agar segala prinsip dasar dapat terlaksana dan segala tujuan pengajaran dapat dicapai secara efektif. Caracara membawakan pengajaran itu merupakan pola dan urutan umum perbuatan guru murid dalam mewujudkan kegiatan pembelajaran. 


\section{Strategi Pembelajaran Anak Usia Dini}

Sebagaimana terdapat dalam Garis-Garis Besar Program Kegiatan Belajar TK(GBPKB TK), bahwa tujuan program kegiatan pembelajaran anak TK adalah untuk menbantu meletakkan dasar kearah perkembangan sikap, pengetahuan, keterampilan, dan daya cipta yang diperlukan oleh anak dalam menyesuaikan diri dengan lingkungannya dan untuk pertumbuhan serta perekembangan selanjutnya. Sedangkan ruang lingkup program kegiatan pembelajaran meliputi: pembrntukan perilaku melalui pembiasaan dalam pengembangan moral pancasila, agama, disiplin, perasaan emosi, dan kemapuan bermasyarakat, serta pengembangan kemampuan dasar melalui kegiatan yang dipersiapkan oleh guru meliputi pengembangan kemampuan berbahasa, daya pikir, daya cipta, serta keterampilan dan jasmani. ${ }^{26}$

Adapun strategi penbelajaran pada anak usia dini ialah selalu mengedepankan aspek-aspek aktivitas bermain, bernyanyi (bergembira), dan bekerja dalam arti berkegiatan. Bermain, bernyanyi, dan berkegiatan merupakan tiga ciri PAUD, pendidikan aspek apapun hendaknya dilingkupi dengan keaktifan bermain, bernyanyi, dan berkegiatan atau bekerja, ketiga hal ini akan mengasah otak, kecerdasan, emosi, dan keterampilan fisik yang dilakukan dengan ceria, bebas, dan tanpa beban. ${ }^{27}$

Untuk melaksanakan proses pembelajaran di lembaga pendidikan TK sangat membutuhkan suatu strategi pembelajaran yang aktif dan atraktif. ${ }^{28}$ Berbagai aktivitas perlu diterapkan dalam

\footnotetext{
${ }^{26}$ Moeslichatoen R. M. Pd, Metode Pengajaran di TK, (Jakarta: Rineka Cipta, 2004), h. 3

27 Theo Riyanto FIC dan Martin Handoko FIC, Pendidikan Pada Usia Dini, ( Jakarta: Grasindo, 2004), h. 82

${ }^{28}$ Ibid, h. 42
} 
kegiatan pembelajaran seperti, bermain, menari, olahraga, gerak tangan dan kaki, dan apaun yang merupakan aktivitas positif.

Yang dimaksud pembelajaran aktif adalah pembelajaran yang menekankan keaktifan anak didik untuk mengalami sendiri, untuk berlatih, untuk berkegiatan, sehingga baik dengan daya pikir, emosi, dan keterampilannya mereka belajar dan berlatih. Pendidikan ialah sebagai fasilitator yang dapat menciptakan suasana kelas yang demokratis, kedudukan pendidikan adalah sebagai pembimbing dan pemberi arah, sedangkan anak didik merupakan objek sekaligus subjek dan mereka bersama-sama saling mengisi kegiatan, belajar aktif dan kreatif.

Yang dimaksud pembelajaran atraktif adalah suatu proses pembelajaran yang mempesona, menarik, mengasyikkan, menyenangkan, tidak membosankan, bervariasi, kreatif, dan indah. Dalam proses pembelajaran di lembaga pendidikan TK sangan diperlukan pembelajaran yang atraktif. Hal ini karena pada umumnya anak-anak usia dini cepat bosan belajar dan berlatih. Kegiatannya ditentukan oleh suasana hati dan menyenangi halhal yang indah, warna-warni, menggembirakan, dan mengumbar daya imajinasi yang tinggi.

Kedua proses pembelajaran di atas merupakan strategi yang sangat sesuai untuk diterapkan di lembaga pendidikan TK, karena strategi pembelajaran anak usia dini harus menekankan pada kegiatan bermain, mampou menyentuh seluruh aspek perekembangan anak dengan memberi keseempatana langsung pada anak untuk belajar memahami dirinya dan kemampuannya, memahami orang lain dan lingkungannya. Saat bermain anak memiliki kebebasan untuk berimajinasi, mengeksplorasi, dan berkreasi. Hal ini sesuai dengan semboyan yang telah banyak 
dikenal di dunia pendidikan anak usia dini yaitu "Belajar Sambil Bermain Dan Bermain Sambil Belajar"

\section{Metode Pembelajaran Anak Usia Dini}

Adapun metode pembelajaran untuk Anak Usia Dini adalah:

\section{a. Metode Bermain}

Menurut pendidik dan ahli Psikologis, menyatakan bahwa bermain merupakan pekerjaan masa kanak-kanak dan cermin pertumbuhan anak. ${ }^{29}$ Bermain merupakan suatu kegiatan yang dilakukan dengan atau tanpa mempergunakan alat yang menghasilkan pengertian atau memberikan informasi, memberi kesenangan maupun mengembangkan imajinasi pada anak. ${ }^{30}$ Bermain juga merupaka kegiatan yang memberikan kesenangan dan dilaksanakan untuk kegiatan sendiri, yang lebih ditekankan pada caranya dari pada hasilnya yang diperoleh dari kegiatan itu. ${ }^{31}$

\section{b. Metode Karyawisata}

Bagi anak TK karyawisata berarti memperoleh kesempatan untukmengobservasi, memperolehinformasi, ataumengkajisegala sesuatu secara langsung. ${ }^{32}$ Berkaryawisata memberikan makna penting bagi perkembangan anak karena dapat mengembangkan minat anak pada suatu hal, memperluas perolehan informasi, juga akan memperkaya lingkup program kegiatan belajar anak TK yang

${ }^{29}$ Gordon, Ann Milles nad Kathryn Willian Brown, Begining and Beyond: Foundations in early chilhood education, ( New York: Delmar Publishing Inc, 1985), h. 266

${ }^{30}$ Anggani Sudono, Pedoman Pendidikan Prasekolah, (Jakarta: Grasindo, 1991), h. 1

${ }^{31}$ Dworetzky, John P. Introduction to Child Development, 4 th ed, (New York: West Publishing Company, 1990), h. 395

32 Welton, David A and John T Mallan, Children and Their World, (Strategis For Teaching Sosial Studies. 2 nd, ed, (New Jersey: Hougton Mifften Company Boston, 1981), h. 414 
tidak dapat dihadirkan di kelas.seperi melihat bermacam-macam hewan, mengamati proses pertumbuhan, tempat-tempat khusus dan pengelolaannya, bermacam-macam kegiatan transportasi, lembaga sosial dan budaya. ${ }^{33}$ Jadi dari karyawisata anak dapat belajar dari pengalaman sendiri dan sekaligus anak dapat melakukan generalisasi berdasarkan sudut pandang mereka.

\section{c. Metode Bercakap-cakap}

Bercakap-cakap berarti saling mengkomunikasikan pikiran dan perasaan secara verbal. ${ }^{34}$ Bercakap-cakap mempunyai makna penting bagi perkembangan anak TK karena bercakap-cakap dapat meningkatkan keterampilan berkomunikasi dengan orang lain, meningkatkan keterampilan dalam melakukan kegiatan bersama, dan juga meningkatkan keterampilan menyatakan perasaan, serta menyatakan gagasan atau pendapat secara verbal. ${ }^{35}$

Oleh karena itu, penggunaan metode ini bagi anak TK akan membantu perkembangan dimensi sosial, emosi, kognitif, terutama bahasa.

\section{d. Metode Bercerita}

Bercerita merupakan cara untuk meneruskan warisan budaya dari satu generasi kegenerasi berikutnya. ${ }^{36}$ bercerita juga dapat menjadi media untuk menyampaikan nilai-nilai yang berlaku di masyarakat. Bercerita mempunyai makna penting bagi perkembangan anak TK karena melalui bercerita kita dapat:

\footnotetext{
${ }^{33}$ Moeslichatoen R. M. Pd, Op. Cit., h. 25

${ }^{34}$ Hildebran, Verna, Introduction to Early Chilhood Education. 4 nd, ed, (New York: Mac Millan Publishing Company, 1986), h. 314

${ }^{35}$ Moeslichatoen R. M. Pd, Op. Cit.,h. 25

${ }^{36}$ Gordon dan Browne, Op. Cit., h. 324
} 

a) Mengkomunikasikan nilai-nilai budaya
b) Mengkomunikasikan nilai-nilai sosial
c) Mengkomunikasikan nilai-nilai keagamaan
d) Menanamkaan etos kerja, disiplin waktu, dan ramah lingkungan
e) Membantu mengembangkan fantasi anak
f) Membantu mengembangkan dimensi kognisi anak
g) Membantu mengembangkan dimensi bahasa anak. ${ }^{37}$

\section{e. Metode Demonstrasi}

Demonstrasi berarti menunjukkan dan menjelaskan. Jadi dalam demonstrasi kita menunjukkan dan menjelaskan caracara mengerjakan sesuatu. Melalui metode ini diharapkan anakanak dapat mengenal langkah-langkah pelaksanaan. Metode ini mempunyai makna penting bagi anak TK, yang antara lain:

a) Dapat memperlihatkan secara konkrit apa yang dilakukan

b) Dapat mengkomunikasikan gagasan, konsep, prindip dengan peragaan

c) Membantu mengembangkan kemampuan mengamati secara teliti dan cermat

d) Membantu mengembangkan kemampuan untuk melakukan segala pekerjaan secara teliti, cermat, dan tepat

e) Membantu mengembangkan kemampuan peniruan dan pengenalan secara tepat. ${ }^{38}$

\footnotetext{
${ }^{37}$ Moeslichatoen R. M. Pd, Loc. Cit.

${ }^{38}$ Ibid, h. 27
} 


\section{4 \\ JURNAL AL-AFKAR \\ Vol. III, No. 1, April 2015}

f. Metode Proyek

Metode proyek adalah salah satu metode yang digunakan untuk melatih kemampuan anak memecahkan masalah yang dialami anak dalam kehidupan sehari-hari. Cara ini juga dapat menggerakkan anak untuk melakukan kerjasama sepenuh hati dan kerjasama dilaksanakan secara terpadu untuk mencapai tujuan bersama.

Kegiatan proyek mempunyai makna penting bagi anak TK, karena kegiatan ini berkaitan dengan kehidupan anak seharihari yang dapat dihubungkan satu dengan yang lain dan dapat dipadukan menjadi suatu hal yang menarik bagi anak, selain itu juga bersifat fleksibel. ${ }^{39}$

g. Metode Bernyanyi

Menyanyi atau mendengarkan musik merupakan bagian dari kebutuhan alami individu. Melalui nyanyian dan musik, kemampuan apresiasi anak akan berkembang dan melalui nyanyian anak dapat mengepresiasikan segala pikiran dan isi hatinya. Adapun manfaat dari metode bernyanyi di antaranya:
a) Memberikan suasana senang
b) Mengasah emosi
c) Membantu menguatkan daya ingat
d) Mengasah kemampuan apresiasi, imajinasi, dan kreasi
e) Sebagai alat dan media pembelajaran. ${ }^{40}$

\footnotetext{
39 Hildebran, Op. Cit., h. 380

${ }^{40}$ Hibana S. Rahman, Konsep Dasar Pendididikan Anak Usia Dini, (Yogyakarta: PGTKI Press, 2005), h. 91
} 


\section{h. Metode Tugas}

Pemberian tugas merupakan pekerjaan tertentu yang dengan sengaja harus dikerjakan oleh anak yang mendapat tugas. Di TK tugas diberikan dalam bentuk kesempatan melaksanakan kegiatan sesuai dengan petunjuk langsung guru. Dengan pemberian tugas, anak dapat melaksanakan kegiatan secara nyata dan menyelesaikannya sampai tuntas. Pemberian tugas mempunyai makna penting bagi anak TK, karena:

a) Pembagian tugas secara lisan akan memberi kesempatana pada anak untuk melatih persepsi pendengaran mereka

b) Pemberian tugas melatih anak untuk memusatkan perhatian dalam jangka waktu tertentu

c) Pemberian tugas dapat membangun motivasi anak. ${ }^{41}$

Selanjutnya selain metode, yang termasuk dalam strategi pembelajaran adalah bahan dan pembelajaran anak TK.

Berdasarkan karakteristik perkembangan anak dan metode pembelajaran yang diterapkan untuk anak TK, maka ada beberapa kriteria untuk menentukan bahan dan perlengkapan belajar anak usia dini, yaitu:

1. Relevan dengan kondisi anak

2. Berwarna dan antraktif

3. Sederhana dan konkrit

4. Eksploratif dan mengundang rasa ingin tahu

5. Berkait dengan aktivitas keseharian anak

6. Aman dan tidak membahayakan

7. Bermanfaat dan mengandung nilai pendidikan. ${ }^{42}$

\footnotetext{
${ }^{41}$ Moeslichatoen R. M. Pd, Op. Cit.,h. 28

${ }^{42}$ Hibana S. Rahman, Op. Cit., h. 76
} 
$26 \frac{\text { JURNAL AL-AFKAR }}{\text { Vol. III, No. I, April } 2015}$

\section{E. Manfaat Pelaksanaan Pembelajaran Anak Usia Dini}

Adapun manfaat dari pelaksaan pembelajaran anak usia dini adalah:

1. Mengembangkan seluruh kemampuan yang dimiliki anak sesuai dengan tahap perkembangannya

2. Mengenalkan anak pada dunia sekitar

3. Mengembangkan nilai-nilai sosial anak

4. Mengenalkan peraturan dan menanamkan disiplin pada anak

5. Memberikan kesempatan kepada anak untuk menikmati masa bermainnya. ${ }^{43}$

Karena misi dan fungai pembelajaran di lembaga pendidikan TK ialah untuk membimbing dan membelajarkan anak sambil bermain, memperluas pengenalan anak terhadap dunianya dan lingkungan masyarakatnya serta sedapat mungkin mempersiapkan mental untuk menghadapi pendidikan selanjutnya.

${ }^{43}$ Ibid, h. 9 


\section{DAFTAR PUSTAKA}

Anggani Sudono, Pedoman Pendidikan Prasekolah, (Jakarta: Grasindo, 1991).

Anwar Arifin. Memahami Paradigma Baru Pendidikan Nasional dalam UU SISDIKNAS, (Jakarta; Departemen Agama RI, 2003).

Dworetzky, John P. Introduction to Child Development, 4 th ed, (New York: West Publishing Company, 1990).

Edy Gustian, Mempersiapkan Anak Masuk Sekolah, (Jakarta; Puspa Swara, 2001).

Gordon, Ann Milles nad Kathryn Willian Brown, Begining and Beyond: Foundations in early chilhood education, ( New York: Delmar Publishing Inc, 1985).

Harsya, W. Bachtiar. Dkk, Ensiklopedi Indonesia jld 6, (Jakarta: Ichtiar Baru Van Hoeve).

Hibana S Rahman, Konsep Dasar Pendidikan Anak Usia Dini, (Yogyakara; PGTKI Press, 2005).

Hildebran, Verna, Introduction to Early Chilhood Education. 4 nd, ed, (New York: Mac Millan Publishing Company, 1986).

Lalu Muhammad Azhar, Proses Belajar Mengajar Pola CBSA, (Surabaya: Usaha Nasional, 1999).

Moeslichatoen R. M. Pd, Metode Pengajaran di TK, (Jakarta: Rineka Cipta, 2004).

Moeslichatoen R. M. Pd, Metode Pengajaran di TK, (Jakarta; Rineka Cipta, 2004). 
Nana Sudjanam, Wari Suwariyah, Model-Model Mengajar CBSA, (Bandung: Sinar Baru, 1991).

Nazali Shaleh Ahmad, Pendidikan dan Masyarakat, (Yogyakarta; Bina Usaha, 1989).

Prawira Mangkut. Tb Syafri, manajemen Sumber Daya Manusia Strategik, (Jakarta: Ghalia Indonesia, 2003)

Soedarjono, Pendidikan Prasekolah pada Beberapa Negara di Dunia, (Semarang; Mandira, 1988).

Soegarda Poerbakawatja. H. A.H. Harahap, Ensiklopedi Pendidikan, (Jakarta : Gunung Agung, 1981).

Soemiarti Patmonodewo, Pendidikan Anak Prasekolah, (Jakarta; Rineka Cipta, 2003).

Syaiful Bahri Djamarah, Aswan Zain, Strategi Belajar Mengajar, (Jakarta: Rineka Cipta, 2006).

T. Raka Joni, Strategi Belajar Mengajar, (Jakarta: P3G Depdikbud) Theo Riyanto FIC dan Martin Handoko FIC, Pendidikan Pada Usia Dini, ( Jakarta: Grasindo, 2004),

Theo Riyanto FIC, Martin Handoko FIC, Pendidikan pada Usia Dini, (Jakarta; Grasindo, 2004).

W. Gulo, Strategi Belajar Mengajar, (Jakarta: Widiasarana Indonesia, 2002).

Welton, David A and John T Mallan, Children and Their World, (Strategis For Teaching Sosial Studies. 2 nd, ed, (New Jersey: Hougton Mifften Company Boston, 1981) 